\title{
Approved Method of Recovery Arsenic by Using Reference Materials by FI-HG-AAS
}

Mostafa Hasani $^{1 *}$, Mohammad Rasoul Hadiani ${ }^{2}$ and Fatemeh Mohammadnia ${ }^{3}$

${ }^{1}$ Department of Pharmacology, Tehran University of Medical Sciences, Iran

${ }^{2}$ Heavy Metals Analysis Lab, Food and Drug Laboratories Research Center, Food and Drug Organization, Tehran, Iran

${ }^{3}$ Viromed Lab, Azadi, Tehran, Iran

\begin{abstract}
A flow injection hydride generation atomic (FI-HG-AAS) method was developed for determination of arsenic in certified reference materials after open wet digestion of samples. Steps of the method were optimized and analytical as well as statistical parameters of the method were determined (Detection limit $1 \mu \mathrm{g} / \mathrm{kg}^{-1}$, Quantification limit $3 \mu \mathrm{gg} / \mathrm{kg}^{-1}$ ). Accuracy of the method was evaluated using GBW10043 (Rice), GBW100052 (Green tea), T0770 (soya flour), NCS-ZC 73013 (Spinach), NCS-ZC 73015 (Milk powder) reference materials.
\end{abstract}

Keywords: Arsenic; FI-HG-AAS; Food contaminants; Certified reference materials

\section{Introduction}

The world health organization has recommended a provisional maximum tolerable daily (PMTD) of $2.1 \mu \mathrm{g} / \mathrm{kg}$ body weight per day for inorganic arsenic [1]. Arsenic in most food contains low levels of arsenic, normally below $0.25 \mathrm{mg} / \mathrm{kg}$, exception of some kinds of fish, crustaceans and seaweed [2]. The environmental protection agency recently decreased the maximum permissible concentration of arsenic in drinking water to $0.01 \mathrm{mg} / \mathrm{L}$ [3]. Approximately $80 \%$ of arsenic compounds are used in pesticides other uses include glassware, paints, and pigments. Arsine gas is used in the semiconductor industry. Arsenic compounds occur in three forms: $1-\mathrm{As}^{5+}$ pentavalent, organic or arsenate compounds (e.g., alkyl arsenates); $2-\mathrm{As}^{3+}$ trivalent, inorganic compounds (e.g., sodium arsenate, arsenic trioxide); 3-Arsine gas $\mathrm{AsH}_{3}$ a colorless gas formed by the action of acids on arsenic [4]. Several analytical methods for the quantitative determination of arsenic in biological, environmental and industrial samples have been reported. Estimation of arsenic in most of environmental/biological samples warrants the development of trace analysis methodology with detection limit at ppb. arsenic in the environment is likely to be oxidized to $\mathrm{As}^{5+}$ oxidation state in aerobic condition, so we be converted $\mathrm{As}^{5+}$ to $\mathrm{As}^{3+}$ for the measurement. FI-HG-AAS has been a valuable method to determine Arsenic, Antimony and Selenium in environmental materials. In this article, we device parameters and sample preparation method for the measurement of arsenic express.

\section{Materials and Methods}

\section{Sample collection}

The most well-known five certified reference materials GBW10043 (Rice), GBW100052 (Green tea), NCS -ZC 73013(spinach), NCS-ZC 73015(Milk powder) China National Analysis Center for Iron and Steel, Beijing, China and T0770 (soya flour) (FAPAS York, UK) were collected which was used to measure arsenic.

\section{Standards and reagents}

Analytical reagent-grade chemicals from Chem-lab (Belgium), Merck Millipore and Deionised water with the electrical conductivity of less than $1 \mu \mathrm{s} / \mathrm{cm}$ were used for preparation of all solution and sample dilutions. standards of arsenic (1000 mg/ $/ \mathrm{L}^{-1}$ stock solution Chem-lab) was used for to prepare the working standard $\left(1,2.5,5,10 \mu \mathrm{g} / \mathrm{L}^{-1}\right)$ in $\mathrm{HCl}$
3\% (Merck Millipore) and the use of 5\% potassium iodide (Chem-lab) in 5\% ascorbic acid (Merck Millipore) for reducing $\mathrm{As}^{5+}$ to $\mathrm{As}^{3+}$. Carrier solution $\mathrm{Hcl} 3 \%$ and $0.3 \% \mathrm{NaBH}_{4}$ (Merck Millipore) in $0.05 \% \mathrm{NaOH}$ reducing agent to produce hydride to used. All volumetric containers and pipettes were soaked in 20\% nitric acid (Merck Millipore) overnight and rinsed with Deionised water prior to analysis.

\section{Instrumentation}

A Perkin Elmer model 4100 atomic absorption spectrophotometer (Germany), equipped with flow injection analysis system (FIAS 200) with an Electro thermal Quartz flow throw cell atomizer was used for the hydride atomization fixed at $900^{\circ} \mathrm{C}$. Table 1 shows parameters for determination of arsenic in the samples, using FIAS 200 (Table 1).

\section{Preparation of sample}

For analysis arsenic the content of each certified reference materials with matrix different remove from the refrigerator and the homogenized sample and laid out to reach room temperature. To determine the concentration of arsenic initial mineralization on samples was performed using an open wet digestion. 0.2 gram of a homogenized sample was moved to a Erlenmeyer flask $100 \mathrm{ml}$ and $1 \mathrm{ml}$

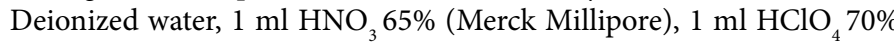
(Merck Millipore) and $5 \mathrm{ml} \mathrm{H}_{2} \mathrm{SO}_{4} 98 \%$ (Merck Millipore) was added.

\section{FIAS 200 Recommended Analytical Parameters for Arsenic}

Parameters Technique: AA

Wavelength: $193.7 \mathrm{~nm}$ Integration Time: $15 \mathrm{sec}$

Data Processing Smoothing: 19 points Cell Temperature: $900^{\circ} \mathrm{C}$

Reagents

Carrier Solution: $3 \%(\mathrm{v} / \mathrm{v}) \mathrm{Hcl}$

Reducing Agent: $0.3 \% \mathrm{NaBH}_{4}$ in $0.05 \% \mathrm{NaOH}$

Table 1: Parameters for determination of arsenic in the samples, using FIAS 200.

*Corresponding author: Mostafa Hasani, Department of Pharmacology Tehran University of Medical Sciences, Iran, Tel: +982188896696; E-mail: hasanim781@gmail.com

Received February 04, 2017; Accepted February 20, 2017; Published March 03 2017

Citation: Hasani M, Hadiani MR, Mohammadnia F (2017) Approved Method of Recovery Arsenic by Using Reference Materials by FI-HG-AAS. J Environ Anal Toxicol 7: 443. doi: 10.4172/2161-0525.1000443

Copyright: (๑) 2017 Hasani M, et al. This is an open-access article distributed unde the terms of the Creative Commons Attribution License, which permits unrestricted use, distribution, and reproduction in any medium, provided the original author and source are credited. 
Citation: Hasani M, Hadiani MR, Mohammadnia F (2017) Approved Method of Recovery Arsenic by Using Reference Materials by FI-HG-AAS. J Environ Anal Toxicol 7: 443. doi: 10.4172/2161-0525.1000443

Page 2 of 2

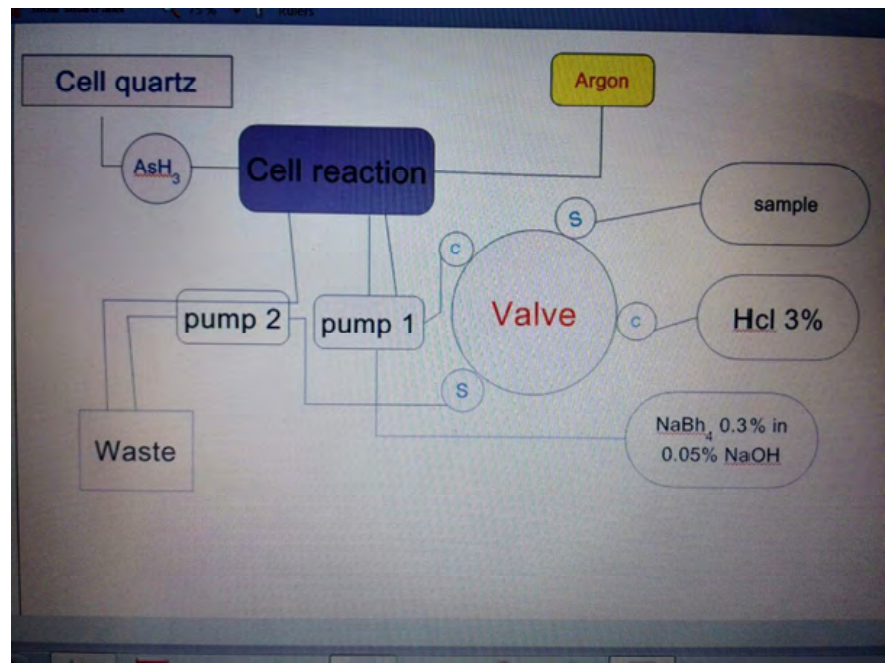

Figure 1: Diagram for FIAS 200.

\begin{tabular}{|c|c|c|c|c|c|c|c|c|c|c|}
\hline Analyte & \multicolumn{2}{|c|}{ GBW10043 (Rice) } & \multicolumn{2}{|c|}{ GBW100052 (Green tea) } & \multicolumn{2}{|c|}{ NCS -ZC 73013(spinach) } & \multicolumn{2}{|c|}{ NCS-ZC 73015 (Milk powder) } & \multicolumn{2}{|c|}{ T0770 (soya flour) } \\
\hline \multirow[t]{2}{*}{ As } & $\begin{array}{l}\text { Assigned } \\
\text { value }(\mathrm{ng} \\
\left.\mathrm{kg}^{-1}\right)\end{array}$ & $\begin{array}{l}\text { Reference value } \\
\quad\left(\mathrm{ng} \mathrm{kg}^{-1}\right)\end{array}$ & $\begin{array}{l}\text { Assigned } \\
\text { value (ng } \\
\left.\quad \mathrm{kg}^{-1}\right)\end{array}$ & $\begin{array}{l}\text { Reference value } \\
\quad\left(\mathrm{ng} \mathrm{kg}^{-1}\right)\end{array}$ & $\begin{array}{c}\text { Assigned } \\
\text { value (ng } \\
\left.\mathrm{kg}^{-1}\right)\end{array}$ & $\begin{array}{l}\text { Reference } \\
\text { value (ng } \\
\left.\mathrm{kg}^{-1}\right)\end{array}$ & $\begin{array}{c}\text { Assigned } \\
\text { value (ng } \\
\left.\quad \mathrm{kg}^{-1}\right)\end{array}$ & $\begin{array}{c}\text { Reference } \\
\text { value }\left(\mathrm{ng} \mathrm{kg}^{-1}\right)\end{array}$ & $\begin{array}{l}\text { Assigned } \\
\text { value (ng } \\
\left.\quad \mathrm{kg}^{-1}\right)\end{array}$ & $\begin{array}{c}\text { Reference } \\
\text { value }\left(\mathrm{ng} \mathrm{kg}^{-1}\right)\end{array}$ \\
\hline & $117 \pm 2.1$ & $96-132$ & $267 \pm 6.4$ & $220-320$ & $212 \pm 2.2$ & $200-260$ & $34 \pm 1.8$ & $24-38$ & $303 \pm 3.8$ & $188-421$ \\
\hline
\end{tabular}

Table 2: Recovery of test of reference of materials.

In order to exit the produced gases and the beginning of oxidation the Erlenmeyer were placed under hood for 20 minutes and then moved on the hotplate with $50-60^{\circ} \mathrm{C}$. Digestion to appearance of white vapor continues, and of sample the remaining $1 \mathrm{ml}$. then the warm solution was left for a 10 minute to reach room temperature and $5 \mathrm{ml}$ of $5 \%$ potassium iodide (Chem-lab) in 5\% ascorbic acid (Merck Millipore) were added. The solution was diluted to $10 \mathrm{ml}$ with Deionized water. the prepared solution reduce $\mathrm{As}^{5+}$ to $\mathrm{As}^{3+}$ for 1 hours which makes the solution ready for analysis.

\section{Hydride generation system}

The HG apparatus is illustrated in Figure 1.

\section{Method validation}

For determination of methods accuracy, recovery tests were performed by certified reference materials samples GBW 10043 (Rice), GBW100052 (green tea), NCS-ZC 73013 (spinach), NCS-ZC 73015 (Milk powder) National Analysis Center for Iron and Steel Beijing, China and T0770 (soya flour) (FAPAS, York, UK) which demonstrated good agreement (Table 2), the limit of detection (LOD) and the limit of quantification (LOQ) of the test methods were defined as signal-tonoise ratios of 3 and 10, respectively [5]. LOD and LOQ for the analyzed heavy metals in sample solution were 1.0 and $3.0 \mu \mathrm{g} / \mathrm{kg}^{-1}$ for arsenic.

\section{Discussion and Conclusion}

It has been shown that this method can be successfully applied to the determination of arsenic in these types of reference materials. The open Wet Digestion System gave completely digested, clear samples with no loss of arsenic during the given temperature. The Perkin Elmer with FIAS 200 gave good spike recoveries with no matrix interference. Extraction and analysis method described in the article compared with other work done like Rajakovic et al. [6], Wang et al. [7], Niedzielski et al. [8], highly functional and cost-effective in terms of time is.

\section{References}

1. WHO (2010) Safety evaluation of certain food contaminants. World Health Organization, Geneva, Food Additives Series No 63.

2. Jelinek CF, Corneliussen PE (1977) Levels of arsenic in the United States food supply. Environmental health perspectives 19: 83-87.

3. Robert SH, Mary AH, Neal AL, Lewis SN, Lewis R (2011) Goldfrank's Toxicologic Emergencies, 10e.

4. Hodgson E (2004) A textbook of modern toxicology. John Wiley \& Sons.

5. ICH (2005) The International Conference on Harmonization of Technical Requirements for Registration of Pharmaceuticals for Human Use. Harmonized tripartite guideline, Validation of analytical procedures: Text and Methodology Q2 (R1).

6. Rajaković LV, Todorović ŽN, Rajaković-Ognjanović VN, Onjia AE (2013) Analytical methods for arsenic speciation analysis. Journal of the Serbian Chemical Society 78: 1461-1479.

7. Zhongwen W, Don F (2012) Methods for the Determination of Arsenic Speciation in Rice. Encyclopaedia of Analytical Chemistry.

8. Niedzielski P, Siepak M (2003) Analytical methods for determining arsenic, antimony and selenium in environmental samples. Polish Journal of Environmental Studies 12: 653-668. 